\title{
La función de la metáfora organicista en la obra de Alonso de Cartagena*
}

\author{
Francisco CASTILLA URBANO \\ Universidad de Alcalá \\ (francisco.castilla@uah.es)
}

\begin{abstract}
RESUMEN
Alonso de Cartagena (1385-1456) aplica la metáfora organicista a la república y a la Iglesia. En ésta, a través de la doctrina del corpus mysticum, enfatiza la igualdad de todos los fieles, independientemente de su origen, favoreciendo claramente la integración de los conversos, grupo al que él mismo pertenecía, en la comunidad cristiana. Al aplicarla a la sociedad, el obispo de Burgos subraya la diferencia de rango de sus integrantes, pero, poniendo al monarca como cabeza de ese cuerpo político, reconoce la necesidad de que las acciones de sus distintos miembros, y especialmente de los más destacados, se encaminen al bien público
\end{abstract}

PALABRAS CLAVE: Alonso de Cartagena; metáfora organicista; conversos; integración religiosa; legitimación monárquica

\begin{abstract}
Alonso de Cartagena (1385-1456) organic metaphor applies to the republic and the Church. In this, through the doctrine of corpus mysticum emphasizes the equality of all believers, regardless of their origin, clearly favoring the integration of converses, a group that he belonged in the Christian community. When applied to society, the bishop of Burgos highlights the difference in status of its members, but putting the monarch as head of that political body, recognizes the need for the actions of its individual members, and especially the most prominent, are directed towards the public good
\end{abstract}

KEY WORDS: Alonso de Cartagena; organic metaphor; conversos; religious integration; monarchical legitimacy

\section{El lugar de la metáfora organicista en el pensamiento.}

Lejos de ser un añadido retórico más o menos afortunado, la metáfora desempeña un papel constitutivo en el proceso de pensamiento, lenguaje y acción ${ }^{1}$. Su función es ordenar conceptualmente nuestra experiencia, de manera que lo que resalta o rebaja no es sólo una forma literaria sino que se convierte en objeto de mayor o menor interés en la realidad. Aplicada al terreno político, la metáfora crea imágenes de la sociedad y de su gobierno que nos hacen concebirlos, expresarlos y actuar conforme a unas características que parecen serles inherentes ${ }^{2}$. En estas imágenes la descripción y la prescripción suelen ir de la mano, determinando en forma de paradigma lo que es y lo que queda excluido del mundo.

Así, una de las metáforas más utilizadas es la que afecta al organismo. El uso del término corpus para designar cualquier forma de comunidad o sociedad e incluso al Esta-

\footnotetext{
${ }^{1}$ G. LAKOFF y M. JOHNSON, Metáforas de la vida cotidiana. Madrid. Cátedra, 2009 (1980), 39.

2 J. M. GONZÁLEZ GARCÍA, Metáforas del poder. Madrid. Alianza Ed., 1998, 21.
} 
do, introduce en el terreno político y religioso lo que es percibido como propio de un dominio biológico. La imaginación extiende con ello el dominio natural al mundo cultural y las ideas de nacimiento, crecimiento, desarrollo, parálisis, enfermedad, salud, crisis o muerte adquieren nuevo alcance. Bajo el paraguas de la metáfora corporal aparecen nuevas formas de concebir realidades sociales, religiosas o políticas con diferentes presupuestos. De ahí que cada cambio de significado, cada matiz en su uso, la extensión de su aplicación a uno u otro contexto o las múltiples interpretaciones de la metáfora que se originan reclamen una atención diferenciada.

La teoría según la cual la sociedad es como un cuerpo y los individuos que la constituyen equivalen a los miembros del mismo, tiene sus antecedentes en la antigüedad clásica y en las propias Escrituras. Tanto en Platón ${ }^{3}$ como en Aristóteles ${ }^{4}$ podemos apreciar algunos esbozos de una concepción organicista de la polis. Sin embargo, la mayor parte de los escritores de la Edad Media que hacen uso de la metáfora o analogía ${ }^{5}$ organicista no remiten en sus citas a los grandes filósofos griegos, sino a san Pablo ${ }^{6}$. Aunque sin duda estamos ante un tema que se repite en las letras de cualquier época ${ }^{7}$, se podría decir que durante la primera parte del período medieval no se prestó la misma atención a la formulación de la metáfora tal y como era posible apreciarla en los textos del mundo antiguo, mientras que se divulgó extraordinariamente el mensaje paulino procedente del texto sagrado $^{8}$. Esto no significa que la propia adaptación medieval de la metáfora estuviera exen-

\footnotetext{
${ }^{3}$ República, 369a y 462cd; Leyes, 964d-965a; etc.

${ }_{4}^{4}$ Politica, 1253a19-24, 1254a31-33, 1277a5-10, 1287b25-31, 1290b24-1291a10, 1302b33-1303a2, 1325b1430 , etc.

${ }^{5}$ En el presente estudio no se distingue entre ambos términos. Un intento de diferenciación que no es seguido por el propio autor, en T. SHOGIMEN, "Treating the Body Politic: The Medieval Metaphor of Political Rule in Late Medieval Europe and Tokugawa Japan”, The Review of Politics, 70, 2008, 77-101 (82). ${ }^{6}$ I Corintios 6, 15; 10, 16-17; 12, 12-27; Efesios 1, 22-23; 2, 16; 3, 6; 4, 4, 16 y 25, y 5, 23-30; Colosenses 2, 19; etc.

7 O. von GIERKE, Teorias politicas de la Edad Media (Edición de F. W. Maitland). Madrid. C.E.C., 1995, 11733, y F. RICO, El pequeño mundo del hombre. Varia fortuna de una idea en la cultura española. Madrid. Alianza Ed., 1988.

8 P. ARCHAMBAULT, "The Analogy of the "Body" in Renaissance political Literature", Bibliothèque d'bumanisme et Renaissance, 29, 1967, 21-53, en 25: "Before the twelfth century, however, the analogy of the body politic was used infrequently. Treatises on the character, duties, and government of princes had, of course, appeared before that time. The comparison of political society to a human organism is rarely used, however; and when it does occur, it is more akin to the Pauline image of the mystical body than to the Aristotelian notion of a political organism".
} 
ta de intereses políticos9. En el Nuevo Testamento aparece expresada de manera explícita, y con una formulación que tendrá enorme influencia en el pensamiento posterior, la doctrina del corpus Christi, que durante la Edad Media dará origen a la teoría del corpus mysticum $^{10}$. La metáfora del cuerpo mistico, constituido por todos los creyentes, que por el bautismo quedan injertados en el cuerpo de Cristo e identificados por ello como miembros de la Iglesia, no quedará reducida al plano eclesiástico, sino que servirá para inspirar teorías sociales y políticas de diferente carácter a lo largo de toda la Edad Media.

En el contexto español de los siglos XV y XVI, son numerosos los autores que hicieron uso de la imagen paulina; entre ellos, los que más frecuentemente han atraído la atención de los eruditos tal vez hayan sido los seguidores del humanista Erasmo, conversos en una proporción significativa. Marcel Bataillon llamó la atención sobre el peculiar significado que dicha metáfora adquiere en los escritos de los erasmistas españoles, e incluso llegó a concluir, en su famoso libro Erasmo y España, que el uso de la metáfora paulina puede ser un rasgo suficiente para catalogar la fecha de redacción de un libro ${ }^{11}$.

La trascendencia de la obra del hispanista francés y la rotundidad de sus afirmaciones tenían que atraer necesariamente la polémica. Eugenio Asensio, uno de los más brillantes comentaristas españoles de la obra del autor francés, estimó en exceso atrevido considerar la metáfora del cuerpo místico "como delatora de erasmismo"12. Buscando un antecedente cuya influencia pudiera ensombrecer la del humanista holandés, José Antonio Maravall encontró numerosos autores que habían expresado la idea con anterioridad a Erasmo, pero ninguno de ellos parecía haber trascendido más allá de un ámbito muy re-

\footnotetext{
${ }^{9}$ E. H. KANTOROWICZ, Los dos cuerpos del rey. Un estudio de teología política medieval. Madrid. Alianza Ed., 1985 (1957), 189: "La doctrina corporativa de la Iglesia romana fue resumida y elevada a dogma por el papa Bonifacio VIII, en 1302, en las frases lapidarias de la bula Unam sanctam... El contexto general de la bula no deja duda sobre el vertido de la frase introductoria. Revela el esfuerzo supremo por parte del poder espiritual para contestar y, en lo posible, superar el reto de la incipiente autosuficiencia de los cuerpos políticos seculares".

${ }^{10}$ Ibídem, 191: "el término paulino [corpus Christi] que originariamente designaba a la Iglesia cristiana, empezó ahora a designar a la hostia consagrada; por el contrario, la noción de corpus mysticum, hasta el momento utilizada para describir la hostia, se transfirió paulatinamente -después de 1150- a la Iglesia como cuerpo organizado de la sociedad cristiana, unida en el Sacramento del Altar".

$11 \mathrm{Al}$ hablar de la influencia de Erasmo sobre Alejo de Venegas (Erasmo y España. Estudios sobre la historia espiritual del siglo XVI. Madrid. F.C.E., 1986, 565), afirma que, aunque no existieran otras semejanzas, "traicionaría ya la filiación erasmiana de su sentimiento religioso por el uso que hace de la imagen del cuerpo místico cuyos miembros son todos los cristianos y cuya cabeza es Cristo. Tal vez en otros países haya sido popularizada esta imagen por otros escritores antes de serlo por Erasmo. Pero en España aparece como un rasgo erasmiano por excelencia, y bastaría casi por sí solo para fechar un libro".

${ }^{12}$ E. ASENSIO, El erasmismo y las corrientes espirituales afines. Salamanca. Seminario de Estudios Medievales y Renacentistas, 2000 (1952), 65.
} 
ducido. No pudo señalar ninguna otra fuente alternativa a la influencia del humanista de Rotterdam, aunque no dudó en advertir que el uso de san Pablo en los escritos del siglo XVI no hacía sino profundizar en una tradición arraigada en el pensamiento español, ya que el del cuerpo místico “es un tema que se encuentra difuso y en estado de cuasi tópico en la situación espiritual de la Baja Edad Media española, en espera de que nuevas corrientes de religiosidad lo revivifiquen"13.

\section{La formación de Alonso de Cartagena y su familiaridad con la metáfora organi- cista}

Resulta, por tanto, excesiva la atribución erasmiana asignada por Bataillon a la imagen del cuerpo místico ${ }^{14}$, y por ello se hace más necesario que nunca esclarecer su alcance y significado antes de que la influencia del humanista holandés se manifestara. Por eso nos proponemos en este texto estudiar su uso en los escritos de Alonso de Cartagena (13851456), a quien hay que situar entre los pensadores españoles más relevantes del siglo XV y uno de los autores que citaba de pasada Maravall en su artículo.

El hecho mismo de que Cartagena se convirtiera al cristianismo en 1390, a la vez que su padre, el rabino Salomón Ha-Leví (1353-1435), que adoptaría el nombre de Pablo García de Santa María y llegaría a ser obispo de Burgos, y al que su hijo sucedería en ese cargo (1435), nos indica que estaba, como converso, en las mejores condiciones, mucho antes de la eclosión del erasmismo, para captar y dar expresión a ese sentimiento de comunidad e igualdad que los nuevos cristianos apreciaban en la metáfora del cuerpo místico. Sin embargo, Cartagena no se ocupó del aspecto religioso de la metáfora hasta una fecha muy tardía; sus primeros usos de la misma se inscriben en el orden social y político, algo para lo que debía de estar especialmente dotado por su formación jurídica de raíz escolástica adquirida en la Universidad de Salamanca, donde alcanzó el grado de doctor en leyes. Esta formación incluía, como dejan entrever sus obras, una amplia cultura filosófica y teológica que don Alonso supo usar no sólo para acumular cargos y acceder a los cen-

\footnotetext{
13 J. A. MARAVALL, "La idea del cuerpo místico en España antes de Erasmo" (1956), en Estudios de Historia del Pensamiento Español. Edad Media. Serie Primera. Madrid. Ediciones Cultura Hispánica, 1967, 200.

14 R. SAEZ, "Le corps mystique comme métaphore religieuse", en A. Redondo, dir., Le corps comme métaphore dans l'Espagne des XVI et XVII siècles. París. Publications de la Sorbonne-Presses de la Sorbonne Nouvelle, 1992, 143-153, in 146: "En effet, l'image du corps mystique d'une continuité affirmée -sous son double parcours de métaphore religieuse et politique- dont je ne puis prendre ici l'entière mesure précède et déborde en Espagne la pénétration des écrits érasmiens".
} 
tros de poder político y religioso ${ }^{15}$, sino también para enfrentarse sin complejos al naciente humanismo: al inicio de sus misiones diplomáticas en Portugal, que incluyeron varios viajes entre 1421 y $1427^{16}$, tiene conocimiento de la obra del italiano Leonardo Bruni, y años después, durante su intervención en el Concilio de Basilea (1434-1439), iniciará con él una polémica sobre la traducción latina de la Ética de Aristóteles.

Al margen de las circunstancias políticas que la provocaron, la embajada a Portugal de don Alonso tiene, pues, tres importantes consecuencias culturales: por una parte, da inicio a su conocimiento de las novedades del humanismo; en segundo lugar, confirma su brillo intelectual, del que va a dejar huella entre los hombres de letras lusos y, por último, marca el principio de su obra escrita, que va estar siempre al servicio de la legitimación del poder real y de la divulgación del saber ético entre la nobleza.

Cartagena hace uso de la metáfora organicista desde su primera obra, el Memoriale virtutum, que debió terminarse en el verano de 142217 , y que puede ser considerada una exposición de los libros III-VII de la Ética a Nicómaco, con abundante presencia de los comentarios de Santo Tomás al texto aristotélico ${ }^{18}$. Escrito a instancias del príncipe portugués don Duarte (1391-1438), con motivo de las conversaciones tenidas entre ambos sobre "la materia de las virtudes", en el Memorial no deja de manifestarse esa concepción corporativa que viene a reconocer a cada órgano o miembro de la unidad que forma el cuerpo social una función diferente y, en consecuencia, deberes y derechos distintos. Así, cada individuo contribuye con sus obligaciones según la categoría que tiene y la tarea que le corresponde dentro del todo del que forma parte:

\footnotetext{
15 Maestresala de la Catedral de Cartagena (1414), deán de Compostela (1415) y Segovia (1418), nuncio apostólico y colector pontificio (1417-1427), oidor en la Audiencia Real de Castilla (1415) y consejero real (1421), y, además de embajador a Portugal, al Concilio de Basilea y obispo de Burgos, protagonista de múltiples intervenciones por cuenta de Juan II de Castilla.

16 A. M. SALAZAR, "El impacto humanístico de las misiones diplomáticas de Alonso de Cartagena en la Corte de Portugal entre medievo y renacimiento (1421-31)", en A. D. DEYERMOND, ed., Medieval Hispanic Studies presented to Rita Hamilton. Londres. Tamesis Books Limited, 1976, 215-26; L. FERNÁNDEZ GALLARDO, Alonso de Cartagena (1385-1456). Una biografia politica en la Castilla del siglo XV. Junta de Castilla y León - Consejería de Educación y Cultura. Valladolid, 2002, 121-123, corrige algunas afirmaciones del anterior.

17 L. FERNÁNDEZ GALLARDO, "Legitimación monárquica y nobiliaria en el Memoriale virtutum de Alonso de Cartagena (ca. 1425)", Historia. Instituciones. Documentos, 28 (2001), 91-128, basándose en la referencia al uso del dinero en Canarias, mantiene (92-3) que debió ser en 1425.

${ }_{18}$ M. CAMPOS SOUTO, El Memorial de virtudes: la traducción castellana del Memoriale virtutum de Alfonso de Cartagena. Burgos. Instituto Municipal de Cultura, 2004, 196: "todo lo que sin actor escripto aquí leyeres, al Filósopho e a los glosadores d'él (señaladamente a Thomás) atribuye las palabras que para el ayuntar de la orden o a más claro entender pensé traer".
} 
"segund que las honrras e los bienes tenporales son de distribuir proporçionablemente, así a las honrras e a los peligros se deven llamar los súbditos proporçionablemente, mirada la qualidad de las personas e de las cosas. Ca más vezes son de llamar los cavalleros para defender la república que los labradores, pues que aquellos de las rentas de la república aun en el tienpo de la paz se mantienen, e los labradores esa república con dineros propios e trabajos ayudan, e así en las cosas semejantes"19

Esa misma concepción está presente en las traducciones de Cicerón que, a la vez que escribía el Memorial de virtudes, realizaba para su compañero en la embajada a Portugal Juan Alfonso de Zamora. El 10 de enero de 1422, en Monte Mor-O-Novo, debió de terminar la traducción del De senectute, mientras el De officiis fue trasladado entre enero y el verano de ese mismo año. En el prólogo a este último texto, Cartagena reivindica el saber de los antiguos siempre que coincida con el de la Escritura ${ }^{20}$, una postura que habría de mantener durante el resto de su vida y que retrata muy bien su rigorismo de converso sincero y de hombre de Iglesia, pero, a la vez, esa capacidad de asimilar cuantos argumentos puedan ser favorables a la causa defendida sea cual sea su origen, que no es extraña tampoco a los conversos. Esa misma actitud le llevará, en el Prólogo al De senectute, a establecer la superioridad de los cristianos sobre los paganos de la Antigüedad en su interés por la ciencia, al mismo tiempo que, más en relación con la metáfora organicista, detalla esa noción de una sociedad estamental en la que a cada cual corresponde ocuparse de la función que le caracteriza, sin que ello implique renuncia al saber, en la medida que le sea posible a cada uno:

"E si éstos [los sabios antiguos] sin fe a fin de saber tanto codiçiavan la sçiençia, ¿qué deven fazer los católicos, que allende deste fin tienden a otro más alto? Non que diga que todos sean letrados, ca la governaçión de la cosa pública non

\footnotetext{
19 Ibídem, 237.

20 Alonso de CARTAGENA, Libros de Tulio: De senetute, De los ofiçios. Edición, prólogo y notas de María Morrás. Universidad de Alcalá. Alcalá de Henares-Madrid, 1996, Prólogo a "Libro de Tulio De los ofiçios", 206: "E por ende, de exercitar es la voluntad e de abivar el spíritu a lectura de las buenas dotrinas e a estudio de aquellos libros que atraen a la vertud, ca non en todos es de poner igual cuidado. Onde Salomón dize: «De fazer libros non ay fin». E es de trabajar prinçipalmente en la Santa Escriptura e en los libros de los católicos e santos doctores, los quales contienen dotrina verdadera e saludable. E siempre aquéllas propuestas e non las partiendo delante los ojos del coraçón es de recrear el spíritu con lectura de los sabidores antiguos, señaladamente aquellas que de las virtudes copiosamente fablaron. E los dichos notables son de sacar e atraer a nuestra dotrina. Onde dizen los santos doctores que los dichos buenos de los gentiles tirarles son para nós commo de injustos poseedores, ca non solamente nos devemos aprovechar de los libros de nuestros doctores, mas aun las buenas dotrinas de los de fuera de la iglesia; si consentáneas e concordes son a la razón natural e ayudan a la buena e católica ordenança de bevir, acarrearlas devemos por que de todas partes sean nuestros actos çercados del muro de la virtud”.
} 
lo padesçe, porque munchos son nesçesarios para labrar la tierra e otros para la defender e algunos para negoçiar e otros para ofiçios e artefiçios que goviernan e fazen fermosa la çivilidad; pero, cada uno en quanto en sí es, debe querer e preçiar el saber. E los que del todo se podieren dar a ello, resçíbanlo con deleitaçión e áyanlo por buen exerçiçio; los otros, deléitense en oír algo. La conclusión sea que por negligencia o menospresçio non quede, ca lo que la necesidad faze, escusable es"21.

Pero sería empobrecedor ver en la metáfora organicista un mero instrumento de distribución de tareas dentro de la sociedad, tanto más rígido cuando del paralelismo de los individuos con los miembros del cuerpo se desprende una cierta dificultad e incluso imposibilidad de cambiar de función. La metáfora no sólo transmite ese valor, ni siquiera resulta ser el más importante, porque el cumplimiento de los diferentes deberes por cada órgano adquiere sentido en beneficio de la cohesión del todo. Se ensalza con ello la unidad del cuerpo social sometido a un orden que liga a todos sus integrantes a la vez que los hace necesarios para el bien de ese cuerpo. Esta idea de la conexión entre los miembros, que va mucho más allá de la sociabilidad hasta convertirse en vínculo espiritual, no pudo pasar desapercibida a don Alonso cuando traducía a Cicerón ${ }^{22}$ y, con un fundamento cristiano, habría de repetirse en sus escritos hasta el final de sus días ${ }^{23}$. Tampoco le sería ajena la legitimidad del tiranicidio, precisamente en nombre de la consistencia que alcanzan los

\footnotetext{
${ }^{21}$ Ibídem, Prólogo a "Libro de Tulio De senetute", 155-6.

22 Ibídem, "Libro de Tulio De los ofiçios", 323: "Ca, si así somos efecçionados que cada uno por su provecho despoje o dañe al otro, nesçesario es que se rompa la compañía del linaje humanal, la qual es mucho segund natura, commo si cualquier de nuestros miembros oviese este sentido, que pensase poder ser sano si atraxiese a sí la sanidad del miembro çercano; ca estonçe nesçesario era que todo el cuerpo enflaqueçiese e peresçiese. Así, si qualquier de nosotros roba para sí los provechos de los otros e por causa de su provecho tira a cada uno lo que puede, nesçesario es que se destruya la compañía e comunidad de los omes".

${ }^{23}$ A. de CARTAGENA, Oracional de Fernán Pérez de Guzmán. Edición para la Biblioteca Saavedra Fajardo de José Luis Villacañas Berlanga. Reproducido de Murcia. Gabriel Luis Ariño (impresor) \& Lope de la Roca (impresor), 26.III.1487 (1454); (23.IV.2010: http:// saavedrafajardo.um.es/ WEB/ archivos/ LIBROS/ Libro0161.pdf), 23: "E cerca desto es de acatar la amistad humana se extiende a otro en dos maneras. La vna es por respecto del mesmo et segund esto la amistad nunca se extiende si non al amigo. La otra manera es por respecto de otro et segund esta manera extiende se a otros, commo acaesce quando alguno tiene amistad con otro: que por causa dél ama a todos los que a él atañen, commo fijos, parientes et seruidores. Et tanto puede ser el amor que con el amigo tenemos que por causa dÉl amamos a los que a él atañen, avnque algunos dellos nos ofendan et non nos quieran bien. E muchas vezes acaesce que por el amor que tenemos a algund amigo sofrimos et tolleramos algunas offensas et errores que nos fazen los suyos et, avnque queriamos que fuessen castigados, pero non les queriamos fazer mal nin los aborrescemos nin queremos mal. E a esta semejança por la amistad que con Dios tenemos et deuemos tener, que llamamos et es caridad, amamos a Él principalmente et segundariamente por causa dél amamos a todos los omnes, pues todos son suyos avnque non sean virtuosos et avnque sean nuestros enemigos et bien deseamos que sean castigados moderadamente, pero non les deuermos tener nin tenemos hodio nin les queriamos mal".
} 
miembros del cuerpo al someterse a las reglas de su buen gobierno, que el tirano viene a destruir ${ }^{24}$. Con ello alcanza Cartagena a establecer la línea que separa al rey legítimo de quien no lo es, cuestión que le ocupará en escritos posteriores y que se convertirá en un argumento a favor de una monarquía que actúa conforme a la ley divina.

\section{Uso político de la metáfora en los escritos de Cartagena}

La familiaridad de Cartagena con los textos antiguos abre las puertas a su consideración de la sociedad y el Estado como un todo orgánico ${ }^{25}$. Sin duda no es ajena a esta concepción del corpus politicum el trasvase del uso religioso de la imagen al civil, que se produce especialmente a partir del redescubrimiento medieval de Aristóteles ${ }^{26}$, y para el que don Alonso estaba especialmente cualificado, tanto como hombre de Iglesia familiarizado con los textos evangélicos, como por sus estudios de derecho civil y canónico en Salamanca. Su conocimiento de los antecedentes paganos y religiosos de la metáfora le permitía aplicarla sin dificultad a cualquier ámbito y su uso inicial de la misma será político y no religioso. Su no menor familiaridad, por otra parte, con los textos jurídicos castellanos facilitaba esta tarea: no hay que olvidar, a este respecto, que si en el solar ibérico las Siete Partidas suponen el triunfo de la concepción política corporativa desde los tiempos de Alfonso

\footnotetext{
24 A. de CARTAGENA, "Libro de Tulio De los ofiçios", o. cit., 326: "Ca non hay alguna compañía entre nós e los tiranos, mas ante soberana diversidad e arredramiento, nin es contra natura despojarle si podieres a aquel a quien matar es cosa honesta. E toda esta menra pestilençial e mala es de destruir e desechar de la comunidad de los omes. Ca así commo algunos miembros se cortan quando comiençan a caresçer de spíritu e de sangre e dañan a las otras partes del cuerpo, así esta feroçidad e crueldad de bestia fiera que está en figura de ome es de apartar e desechar de la comunidad así commo de la humanidad del cuerpo".

25 A. de CARTAGENA, "Discurso sobre la precedencia del rey católico sobre el de Inglaterra en el concilio de Basilea", en Prosistas castellanos del siglo XV. Ed. de M. Penna. Madrid. B.A.E., 1959, 209 a: "así como desimos nobles a las personas singulares, así desimos nobles a las cibdades e a los regnos. E como entre los omes acaesce que uno es noble e otro más, así puede acaecer en las cibdades e en los regnos; ca el derecho que es de una parte a otra parte, esse mesmo derecho se guarda de un todo a otro todo".

${ }^{26}$ E. H. KANTOROWICZ, o. cit., 204: "Hubo todavía otra noción que se hizo popular en el siglo XIII, la noción del «cuerpo político», que resulta inseparable tanto de la época de las tempranas teorías corporativas como del redescubrimiento de Aristóteles. Muy pronto, el término «cuerpo místico» se hizo aplicable a cualquier corpus morale et politicum en el sentido aristotélico. No podemos aventurarnos a valorar la influencia de Aristóteles sobre el lenguaje político bajomedieval, ni siquiera preguntarnos lo que supuso el hecho de que, a partir de entonces, y debido a Aristóteles, el Estado no sólo fuera interpretado como un «cuerpo político», sino también cualificado como «cuerpo moral»o «ético». El Estado, y hasta cualquier otro agregado político, fue concebido como la resultante de la razón natural, como una institución con fines morales intrínsecos y un código ético propio. Los juristas y escritores políticos se vieron ante la nueva posibilidad de comparar o contraponer el Estado como corpus morale et politicum con el corpus mysticum et spirituale de la Iglesia". Véase O. von GIERKE, o. cit., 121.
} 
X (1221-1284), según señaló Maravall27, Alonso de Cartagena demuestra un gran conocimiento de esta obra al glosarla junto con otros textos legislativos en su Doctrinal de los caballeros (ca. 1444). Lo más llamativo de esa aplicación es que Cartagena, sin renunciar a expresar esa hermandad universal ${ }^{28}$ entre los hombres que ya hemos dicho que caracteriza su pensamiento, logra conciliarla con una interpretación vertical de la metáfora que, de acuerdo con el Estagirita ${ }^{29}$, viene a insistir en la necesidad de que existan diferencias sociales para que cualquier sociedad pueda sobrevivir:

"En todos los ayuntamientos de gentes cumple que haya diversos estados para que algún fruto se pueda hacer. Ca según dicen los filósofos, no se podría poblar la ciudad si todos fuesen ricos, ca no habría quién labrase las heredades ni quién quisiese hacer algunas cosas que son necesarias para enderezamiento de la república que son bajas y habidas por viles. Y si todos fuesen pobres, no se podría gobernar la república, porque no habría quién socorriese a los otros en el tiempo de las necesidades. Y por esto son menester hombres de diversas guisas"30

Al aludir a la hermandad primero y a "los ayuntamientos de gentes" en esta última cita, se resalta la imagen de unidad del cuerpo social, pero no deja de advertirse que el buen provecho de esa unión requiere de estados diversos y que, por consiguiente, los miembros del cuerpo no pueden ser iguales, sino que tendrán que diferir en importancia. La cohesión y la ordenación jerárquica que impone la pertenencia al cuerpo aparecen unidas indisolublemente en su uso social, sin que ninguna pueda ser sacrificada en beneficio de la otra. No otra cosa es lo que reconoce don Alonso al Marqués de Santillana cuando le responde el 17 de marzo de 1444, a la qüestión por él planteada sobre "quáles e quántas cosas" contenga el juramento de la caballería: "vos resçebides non pequeña suerte de grandes trabajos, commo vno de los prinçipales mienbros que a nuestro muy soberano príncipe, que es nuestra cabeça, seruiendo ha de sostener e ayudar a la direcçión de la real poliçía"31.

\footnotetext{
${ }^{27} \mathrm{~J}$. A. MARAVALL, "Del régimen feudal al régimen corporativo en el pensamiento de Alfonso X" (1965), en Estudios de Historia del Pensamiento Español. Edad Media. Serie Primera, o. cit., 87-140.

28 A. de CARTAGENA, Tratados Militares. Edición, estudio y notas de N. Fallows. Madrid. Ministerio de Defensa, 2006. Doctrinal de los caballeros, Introducción al Título segundo, 277: "Entre todos los hombres, según dice el jurisconsulto, puso la natura una manera de parentesco".

29 Politica. Ed. de J. Marías y Ma Araújo. Madrid, I.E.P., 1970, 1261a30: "Los elementos que han de constituir una ciudad tienen que diferir cualitativamente".

30 Doctrinal de los caballeros, Introducción al Título seis, 101.

31 Á. GÓMEZ MORENO, "La Qüestión del Marqués de Santillana a don Alonso de Cartagena", El Crotalón, 2, 1985, 350 (en lo sucesivo se citará por Qüestión).
} 
Lo significativo de la cita es que a la vez que se reconoce la superioridad de los miembros relevantes del cuerpo frente a los que no lo son, se eleva por encima de todos, principales y secundarios, a la cabeza, recalcando con ello no tanto la interdependencia entre el príncipe y los miembros como la subordinación de algunos de esos principales como el Marqués. Algo que por estas mismas fechas ya había sido enunciado con carácter general en el Doctrinal de los caballeros ${ }^{32}$, y que viene a poner de manifiesto lo que se ha llamado interpretación personalizadora de la metáfora organicista ${ }^{33}$. No desaparece, sin embargo, la insistencia en la poliçía, esto es, en el orden que ha de existir en la sociedad, y que se identifica con el gobierno que mira al bien común ${ }^{34}$.

Por otra parte, aunque siempre parece pesar sobre las imágenes sociales o políticas medievales una sospecha de hieratismo, sería un error interpretar esta importancia diferente de los miembros del cuerpo político como una apuesta a favor de la inmutabilidad e incomunicabilidad de los distintos estratos sociales. Ya se ha dicho que lo justo en la concepción corporativa es que cada parte de las que constituyen la comunidad cumpla lo que le es propio, es decir, la función que le ha sido asignada para la armonía del todo, pero las peculiaridades de las sociedades medievales hispanas frente al resto de las europeas hacen que el cambio se vea como algo posible. Alonso de Cartagena no se desenvuelve ciertamente en una sociedad abierta que reconoce por igual a todos sus miembros iguales dere-

32 Doctrinal de los caballeros, Introducción al Título cuarto, 95: "Y comoquiera que la cabeza de todos los caballeros y señores seglares sean los emperadores y reyes,...".

33 J. M. NIETO SORIA, Fundamentos ideológicos del poder real en Castilla (Siglos XIII-XVI). Madrid. Eudema, 1988, 93: "En el reino castellano, la doctrina corporativa tuvo una doble interpretación. La que podría denominarse personalizadora, que sería la primera en manifestarse, la que tuvo, por decirlo de alguna manera, un carácter oficial, siendo siempre apoyada desde los medios monárquicos y que llegaría intacta, en cuanto a sus contenidos y vigencia, al término del período aquí analizado. Frente a esta interpretación, existió la que denominaré transpersonalizadora. De aparición más tardía, tuvo una extraordinaria importancia política, por cuanto que estuvo en la base de las argumentaciones que justificaron las sublevaciones más importantes que, contra el poder real, tuvieron lugar en Castilla durante el siglo XV y comienzos del XVI". No hay que descartar que la estancia de $\mathrm{D}$. Alonso en Basilea y las actividades ligadas a la misma le permitieran familiarizarse con la interpretación transpersonalizadora de la metáfora que encarnaban las ciudades del norte y el centro de Italia, y que fue desarrollada por civilistas y canonistas como Bartolo de Saxoferrato y su discípulo Baldo de Ubaldis; véase J. P. CANNING, "The Corporation in the political Thought of the Italian Jurists of the thirteenth and fourteenth Centuries", History of Political Thought, I, 1980, 9-32.

34 Defensorium, Tercera parte, capítulo duodécimo, 386 (según la edición incluida en G. Verdín-Díaz, Alonso de Cartagena y el Defensorium Unitatis Christianae (Introducción histórica, traducción y notas). Universidad de Oviedo, 1992): "tenemos que sacar como principio, y aceptarlo como ciertísimo, que de cualquier manera y para cualquier fin que las ciudades se funden, la disposición, participación y dependencia que se da en las ciudades para gobernar, y a la que llamamos política o "politheuman", es la forma esencial de la ciudad en cuanto que ciudad". Véase N. RUBINSTEIN, "The history of the word politicus in early-modern Europe", en A. PAGDEN, ed., The languages of political theory in early-modern Europe. Cambridge University Press, 1987, 41-56. 
chos y obligaciones y, por consiguiente, la posibilidad de mutar su estado en función de sus méritos; pero la lucha contra los musulmanes ofrece las suficientes oportunidades como para concebir que algunos plebeyos se eleven de su estado social a otros superiores $^{35}$. No obstante, se trate de una nobleza recientemente ganada o de antiguo origen, lo cierto es que ya hemos visto que no alberga duda alguna el Obispo respecto a que la sociedad está integrada por miembros de diversa importancia, y que éstos están llamados a desempeñar funciones diferentes aunque, sean las que sean éstas, todas ellas en beneficio del bien común de la república.

El organismo, por tanto, no puede ser una multitud cualquiera de miembros. Su buen funcionamiento exige una jerarquía, en la que algunos integrantes se reconozcan más valiosos que otros. Pero, con esta consideración, se introduce otro aspecto fundamental de la metáfora: no hay jerarquía sin ordenación, o mejor, la jerarquía es un orden en el que todos los miembros del cuerpo social, sea cual sea su importancia, guardan una posición necesaria, a la vez que atienden a la cabeza gobernante que, como miembro más importante de la comunidad, se encarga de mantener ese orden y dirigirlo hacia el bien común. Éste es un requisito imprescindible para que una multitud de individuos diferentes pueda converger en una vida social próspera. La finalidad del organismo político, la poliçía a la que alude el texto de la Qüestión, es la que posibilita la consecución de la felicidad colectiva, exactamente igual que el individuo persigue la suya particular:

“a semejanza de ellos el que quisiere comprenderlo también lo comprenderá en las cosas místicas, como son las asociaciones, las sociedades, y gran número de pueblos solidariamente unidos, y a los que se acostumbra a llamar cuerpos místicos, pues muestran tener materia y forma, o algo en el lugar de la materia y algo en el lugar de la forma. Y como esto es evidente, también resultará evidente al que lo piense, que no se le llamará ciudad a una multitud de hombres, aunque permanezca reunida en un mismo lugar, a no ser que ordenadamente tienda al bien de la felicidad, porque todas las ciudades y toda participación humana aspiran a algún grado de gobierno"36

\footnotetext{
35 Defensorium, Segunda parte, Teorema cuarto, capítulo vigésimo, 283: "aunque algunos de éstos [campesinos y plebeyos] impulsados por su espíritu y animosidad se eleven a las actividades de la nobleza, y combatan a mano armada, y poco a poco se vayan incorporando al grupo de los nobles, pues la nobleza como el resto de los bienes temporales es granjeable y susceptible de perderse; sin embargo, son pocos los nacidos de padres rústicos y plebeyos los que lo intenten, teniendo en cuenta la cantidad de gente agrupada bajo el nombre de rústico, de plebeyo, o de pueblo, y también de artesano, y de otros oficios que no son propios de los nobles".

36 Ibídem, Tercera parte, capítulo duodécimo, 385.
} 
La comprensión de los distintos agregados sociales (asociaciones, sociedades y pueblos) como "cuerpos místicos" viene a subrayar la equiparación del Estado con la Iglesia, dotando a aquél de una proyección y unas características de superioridad, perdurabilidad, etc., que en principio estaban destinadas exclusivamente a ésta.

Es inevitable, además, extender esa sacralización de lo secular a la persona del monarca, que encabeza ese gobierno responsable de buscar la felicidad. De la misma manera, la referencia a esa forma o "algo en el lugar de la forma", el alma que da vida y movimiento al cuerpo social dirigiéndolo en la dirección adecuada, no puede ser para Cartagena otro que el rey. Ya en el De clementia de Séneca, que el mismo don Alonso adaptó para Juan II, aparece esta idea del emperador como "alma” de la república ${ }^{37}$, una idea que al monarca castellano no le sería indiferente y que pudo haber contribuido a que encargara su traducción ${ }^{38}$. Tampoco sorprendería a Alonso de Cartagena esa imagen, aunque, en su caso, la tentación de convertir el alma en un gobernante absoluto del cuerpo se ve suavizada por su subordinación al bien común. La dirección de la sociedad por el rey en pos de ese bien común no sólo implica una apuesta por la monarquía como forma de gobierno, sino rodear a aquél de un aura moral, casi mística, en la que, no obstante, la finalidad no puede ser dejada de lado. Por eso no sólo reconoce a la Iglesia como cuerpo místico, sino también a la sociedad civil: en ambos casos la persecución de su propio bien, del bien de todo el cuerpo, por encima del que correspondería a la cabeza rectora, es irrenunciable.

La distinción entre el bien del monarca y la del reino que gobernaba ya había sido utilizada por Cartagena en el Discurso sobre la precedencia del rey católico sobre el de Inglaterra (1434), en el que afirma que a su rey “de tamaña virtud le dotó la Providencia divinal, que

${ }^{37}$ De la clemencia, I, 5, 1 (que el texto de Cartagena señala como perteneciente al cap. 6 por error arrastrado desde el cap. 2, lo que no advierte L. Fernández Gallardo, Alonso de Cartagena (1385-1456). Una biografía política en la Castilla del siglo XV, o. cit., 413, nota 333): “tú eres ánima de tu república y la república es tu cuerpo" (1.V.2010: Mss_009990_0027.tif http: // bibliotecadigitalhispanica.bne.es/ view/ action/ nmets. do? DOCCHOICE $=169842 . x m l \& d v s=1274168015960 \sim 953 \&$ locale $=$ es\&search_terms $=$ \&adjacency $=$ \&VIEWER_URL $=/$ view/action/nmets.do?\& DELIVERY_RULE_ID $=$ 4\&usePid1 $=$ true\&usePid2= true).

38 N. G. ROUND, "Alonso de Cartagena and John Calvin as interpreters of Seneca's De clementia", en M. J. Osler, ed., Atoms, 'Pneuma', and Tranquility. Epicurean and Stoic Themes in European Thought. Cambridge. C. University Press, 1991, 80: “These views [de Séneca] had been echoed and developed by medieval jurist from the thirteenth century on. The echoes ha not gone unheeded in Spain and may well themselves have contributed to Juan II's choice of De clementia as a Senecan text for early translation". También L. FERNÁNDEZ GALLARDO, “Cultura jurídica, renacer de la Antigüedad e ideología política. A propósito de un fragmento inédito de Alonso de Cartagena”, En la España Medieval, 16, 1993, 119-34, se plantea (133): “'Acaso la intención de Juan II al encargar la traducción de las obras de Séneca era la búsqueda de fundamentos, referentes doctrinales en que sustentar sus pretensiones autoritarias?”. 
por lo que atañe a su persona non disputaría en alguna manera sobre asentamientos", pero la cuestión de la precedencia sobrepasa la de la persona real para afectar a la dignidad de lo que representa: "pero non deve tener en poco nin dexar a otro la gloria e honor de su real asentamiento"39. El bien, pues, de la institución regia, que por la metáfora organicista es una misma con la sociedad, no puede eludirse y en el ámbito de la política, el bien se alcanza mediante la virtud. Aparece de esta forma lo que Cartagena presenta como una antigua doctrina, aunque renovada modernamente ${ }^{40}$, en la que el monarca es reconocido como el poseedor de la virtud, que de él se expande al pueblo:

“ ¿O cómo se diría guardar el bien común de su tierra quien a su rey non guardase? Ca quien las antiguas doctrinas e ylaçiones modernas que dellas se sacan quisiere acatar fallará que toda la virtud de la república esta ayuntada e complicada en el rey, e la virtud del rey desparzida e esplicada en el pueblo; de guisa que lo que el vno tiene por vía de complicaçión tiene el otro por vía de explicaçión" 41

El ensalzamiento del monarca no es, como puede apreciarse, gratuito. Si algo faltaba a la metáfora organicista era una virtud que, a manera de flujo sanguíneo, recorriera interminablemente el cuerpo articulando a sus miembros con la misma sustancia que surge de su cabeza, convertida en corazón impulsor por exigencias del realismo de la metáfo$\mathrm{ra}^{42}$. La explicaçión, que no es sino manifestación en el todo de la cualidad del uno, garanti-

\footnotetext{
39 A. de CARTAGENA, "Discurso sobre la precedencia del rey católico sobre el de Inglaterra en el concilio de Basilea", o. cit., 206 a. Véase G. DAVIS, "The Development of a National Theme in Medieval Castilian Literature", Hispanic Review, 3: 2, 1935, 149-161, (158): "Cartagena opened his oration by stating that very Catholic king, his lord, was soft-spoken and humble, and that never for himself personally would he dispute priority with anyone. It was then for the honor of Castile that the matter was being argued". La distinción se repite en las Allegationes super conquesta Canariae de Alfonso de Cartagena. Ed. de T. González Rolán, F. Hernández González y P. Saquero Suárez-Somonte. Madrid. UNED, 1994 (1436), 69: "Enrique, infante de Portugal, pidió al rey nuestro señor que se dignara concederle la conquista de aquellas islas; pero el señor rey a pesar de que con gusto hubiera querido complacerle como corresponde a un pariente queridísimo, no obstante puesto que esto concernía al honor de la corona del reino y es una cosa grave segregar de la corona algo, en la cantidad que sea, se excusó dándole sus razones".

40 J. A. PARDOS, "Virtud complicada", en Ch. Continisio y C. Mozzarelli, eds., Repubblica e virtue. Pensiero politico e Monarchia Cattolica fra XVI e XVII secolo. Milan, 1995, 81, identifica el De Docta Ignorantia de Nicolás de Cusa, y su Epistola ad Rodericum de Trevino, dirigida a Sánchez de Arévalo, como la moderna fuente teológica de la que mana esta doctrina del príncipe como legibus solutus. Sin negar tal posibilidad (expresiones de La docta ignorancia, II, III, como "Dios es, por consiguiente, quien complica todas las cosas, porque todas las cosas están en Él; es el que explica todas las cosas, porque Él mismo está en todas”, parecen un precedente claro), hay que insistir en la familiaridad de la metáfora y su interpretación monárquica a partir de Aristóteles y Tomás de Aquino (De regimine principum, I, 2), que nunca adquiere un sentido absoluto, para un hombre de la formación de Cartagena.

${ }^{41}$ Qüestión, 357.

${ }^{42} \mathrm{~J}$. A. MARAVALL, "La idea del cuerpo místico en España antes de Erasmo", o. cit., 181, recoge la cita de "las Cortes del Real sobre Olmedo (1445), donde se dice que «el Rey es cabeça e coraçon e alma del pueblo e ellos son sus miembros»".
} 
za con su propagación la conexión de todas las partes. Aunque al establecer la comparación entre el cuerpo y la república, la metáfora organicista introduce ciertamente un principio de jerarquización que obliga a los miembros del cuerpo a subordinarse a la cabeza que los dirige, la virtud que recorre todo el cuerpo no deja de subrayar la armonía moral existente entre sus partes integrantes ${ }^{43}$. Con ello es posible el ataque a las concepciones feudales más tradicionales y al incipiente republicanismo, una tentación italianizante que la pregunta de Santillana por el contenido del juramento de la caballería demostraba no ser del todo lejana. Como se ha dicho, "la analogía del cuerpo natural y el cuerpo político sirvió para enfatizar la interdependencia de todos los miembros de una sociedad y para sugerir la necesidad de una "cabeza" única. La analogía orgánica fue un argumento en favor de la unidad y la monarquía"44; no se niega, por tanto, la dependencia de las partes respecto de la cabeza regia, que dota a la masa de individuos de orden y unidad ${ }^{45}$. El rey como cabeza de su reino es una garantía tanto para la salud y vitalidad del cuerpo social como para evitar una separación que sería desastrosa para ambos. Pero la analogía en Alonso de Cartagena (y en la mayor parte de los autores que tienden a utilizarla antes del siglo XVII) adquiere su pleno sentido no tanto por la subordinación de las partes a la cabeza, sino por su contribución a la preservación de la unidad del cuerpo y, sobre todo, por la creencia en un orden armónico, sin duda excesivamente idealizado, que excluye tanto la dominación desmesurada como la rebelión, y que supone un servicio sin límites a la república, que se confunde con el monarca:

"Entre muchas cosas que al cavallero se cargan para que tome esta orden e dignamente soporte este nombre, vna es que faga juramento; e qué es lo que ha de jurar diuersos escriptores diuersamente lo escriuieron. Aquel viejo e sotil glosador Acursio legista en algunas leyes del derecho çevill dixo que este sacramento era de non refusar la muerte por la república, es a saber, que non procurará escapar su vi-

\footnotetext{
43 A.-H. CHROUST, "The Corporate Idea and the Body Politic in the Middle Ages", Review of Politics, 9, 1947, 423-52 (424): "The premise of all socio-political thinking of the Middle Ages, namely the idea of a single and uniform but nevertheless articulate whole, presupposed an organic interrelation between this divinely ordained universal whole and its equally divinely ordained parts, members, or individual themselves on the other hand. And since every part of the whole must be connected with the whole as well as with every other part, such a universal order of all created things presupposed, again, a divinely institute barmony which pervades this whole as well as each and every part of it".

${ }^{44} \mathrm{M}$. WALZER, La revolución de los santos. Estudio sobre los orígenes de la política radical. Trad. de S. Villegas. Madrid. Katz Editores, 2008 (1965), 187.

45 E. LEWIS, "Organic Tendencies in medieval Political Thought", The American Political Science Review, XXXII, 5, 1938, 849-76 (858): "the legal personality of the group must necessarily have been placed where medieval thinkers placed it: in the ruler, who alone could give any sort of unity to an otherwise amorphous and discordant mass of individuals".
} 
da donde al bien público cunpliere morir. E esta dotrina siguen algunos modernos legistas que en pos del escriuieron; e en efecto tanbién lo siguieron las leyes deste reyno, pero quisiéronlo más declarar diziendo que non refuse la muerte por defensión de su ley o por seruicio de su rey e señor natural o por el bien de su tierra e pueblo. E esto avnque suena más extenso en palabras, pero bien paresçe con lo al concordar, ca non guardaría bien la república quien a su ley o a su rey o a su pueblo según su poder non guardase" 46

Al poner como límite a la entrega que puede alcanzar esta subordinación el de la muerte, Alonso de Cartagena parece elevar al monarca a señor absoluto. Pero antes de sacar conclusiones apresuradas conviene tomar en consideración lo que ello implica. En primer lugar, es claro que los partidarios de la realeza, entre los que sin duda se encuentra el obispo de Burgos, tienden a confundir el cuerpo místico del reino con el cuerpo místico del monarca. Al equiparar monarca y reino resulta relativamente sencillo reivindicar el derecho a ser defendido ante cualquier amenaza. Sin embargo, el énfasis a la hora de hacer frente al sacrificio se pone más sobre la república, la ley o el pueblo que sobre el rey; éste no aparece nunca aislado, lo que no parece avalar una interpretación a favor de la persona. Aun si éste fuera el caso, tampoco debería extrañar la mención a la inmolación de los caballeros por el monarca puesto que en la concepción organicista éste, como cabeza, corazón o alma, garantiza la supervivencia del todo social; un derivado de este supuesto es que si la contribución de los miembros a la protección del organismo implicara su escisión no se pondría en peligro la continuidad del mismo. También es de destacar que la importancia dada a la tierra y al pueblo, igualmente mencionado en el fragmento reproducido con anterioridad, tiende a unir e incluso a identificarlos con el rey, lo que coincide con el uso de la metáfora organicista en otros autores ${ }^{47}$.

En segundo lugar, la muerte por el rey no es sino una personalización de la devoción por ese cuerpo místico político que se ha venido a equiparar al corpus mysticum religioso. Remite, por tanto, a la disposición a morir por ese cuerpo, república o patria (pro patria morn), cumpliendo un deber que, conforme avanzaba la Edad Media y se aplicaba sistemáticamente la metáfora a los cuerpos políticos, "se consideró igual, en cuanto a valoración y

\footnotetext{
46 Qüestión, 356-7.

47 J. P. CANNING, "The Corporation in the political Thought of the Italian Jurist of the thirteenth and fourteenth Centuries", 23: "The populus is, however, not only an abstract entity; it is also in one aspect identified with its members. They have to live somewhere; they, in short, require a territory. In a notable passage Baldus makes it clear that the populus is nothing less than a territorial entity; that its territorial aspect forms part of what constitutes the populus".
} 
consecuencias, a la muerte por la fe cristiana, por la Iglesia, o por la Tierra Santa"48. No en vano, Cartagena había traducido el mensaje ciceroniano invitando al sacrificio por los príncipes y la tierra en la misma medida que por los padres ${ }^{49}$, y en el Oracional, el obispo de Burgos señala al noble Fernán Pérez de Guzmán que la devoción a la patria ocupa el lugar inmediato tras la religión entre los deberes de cualquier hombre ${ }^{50}$. También desde este punto de vista el trasvase de valores religiosos a la nueva realidad política pasa no sólo por la superación de cualquier lazo de fidelidad familiar o nobiliario en beneficio del que se considera debido a la patria, sino por la encarnación en la figura regia de esa misma fidelidad ${ }^{51}$. Alonso de Cartagena revela con ello su entrega a una monarquía que tiende a reconocer en los letrados como él sus mejores defensores, pero también las ansias del converso que quiere integrarse en un cuerpo poderoso.

Pero, en tercer lugar, la insistencia en que ese cargo del caballero va unido al bien público no deja de representar un aviso sobre los límites del poder regio y la complicidad a la que está obligado con los que gobierna: la que marca la ley y el bienestar de la tierra y del pueblo. La imagen orgánica se convierte en instrumento que enuncia el bien común de la sociedad sin acabar de ceder a las pretensiones absolutistas del monarca ${ }^{52}$. El rey es protector del cuerpo social y debe tener en cuenta la utilidad y beneficio que los miembros de éste transmiten a la totalidad del organismo. Aunque no sea un objeto de fácil compren-

${ }^{48}$ E. H. KANTOROWICZ, o. cit., 255.

49 A. de CARTAGENA, "Libro de Tulio De los ofiçios", 234: "Pero quando todas estas compañías, con toda tu razón e con todo tu corazón las considerares, de todas las compañías non hay ningunas más rezia nin más amada que la que cada uno de nós tiene con la cosa pública. Amados son los padres, amados son los fijos, e los parientes e los servidores, mas todos los amoríos de todos, la tierra donde es ome natural los tiene ayuntados. Por la qual, ¿quál bueno ay que dubde desear la muerte si a su tierra puede aprovechar? Por ende, la crueldad destos que despedeçaron nuestra tierra e son e fueron ocupados en la destruir de fundamento es más aborrecible que todo malefiçio. E si contençión alguna o comparación se faze sobre a quién se debe más ofiçio dar, estos son los prínçipes, e la tierra e los padres, a los benefiçios muy grandes de los quales somos obligados. E çercanos déstos son los fijos e toda nuestra casa, la qual otea a nós solos e non puede aver otra ayuda alguna; e después, los parientes bien concordes, los quales munchas vezes acaece que tienen comunes las faziendas. Por ende, las nesçesarias ayudas de la vida a éstos mayormente se deven que de suso dixe".

50 A. de CARTAGENA, Oracional de Fernán Pérez de Guzmán, 47: "E por esto, despues de Dios, home es mas debdor a aquellos donde desciende et a la tierra donde es natural que llamamos patria que a otro alguno. Por ende, commo a la religion pertenesce fazer el cultu diuinal, asi en el segundo grado es la piedad que consiste en honrar a sus ascendientes et a la patria que es la tierra de la naturaleza".

${ }^{51}$ E. H. KANTOROWICZ, "Pro patria mori in Medieval Political Thought", The American Historical Review, LVI, 1951, 472-92.

52 P. ARCHAMBAULT, "The Analogy of the "Body" in Renaissance political Literature", 31: "the analogy serves a general, unvarying purpose: that of reducing or discouraging whatever absolutist pretentions the Prince might entertain". 
sión siendo, como nos dice que es, materia especulativa, la metáfora organicista adquiere entonces para la sociedad el tinte que habría de adquirir años después en el Defensorium para los cristianos y el que se le atribuye durante la Edad Media a su formulación paulina: son valiosos todos y cada uno de los fieles que componen el cuerpo de Cristo encarnado en su Iglesia, como son valiosos los súbditos a los que se extiende la virtud complicada de su rey:

"Mas esta materia es algunt tanto especulativa e non para aquí, e suélese a las vezes tractar donde la vniuersal Eglesia se fabla; pero non syn razón, a mi parecer, en este logar se interpuso, porque paresca que avnque lo dixeron por diversas palabras, mas la intençión destos dos juramentos toda es vna: ca non guarda la república quien desirue a su rey nin sirve a su rey quien daña al pueblo, segund diríamos que non guarda bien el cuerpo del omne quien le fiere en la cabeça nin le guardaría bien la cabeça quien le firiese en el cuerpo, ca todos los mienbros son coligados e comunican virtud vnos con otros por la proporçión de sus influençias, de guisa que el daño del vno al otro se estiende. Por ende, el buen cauallero que su sacramento quiere guardar deue tener en poco su vida quando syntiere que a defensión de la ley o a serviçio e honor de su rey e prouecho e bien de su tierra cunpliere morir o poner en aventura su vida; e si lo non faze viene contra su profesión, commo el frayle que quebranta su regla" 53

\section{Uso religioso de la metáfora en los escritos de Cartagena}

Las obligaciones de caballeros y frailes se equiparan, como lo hace la metáfora en sus distintos usos. Si durante gran parte de su vida Alonso de Cartagena utilizó la metáfora para mostrar la unidad del pueblo, los nobles y el rey en un único cuerpo, también supo sacarle provecho cuando se trataba de aplicarla a la unión de todos los cristianos. Este es el objetivo del Defensorium Unitatis Christianae, un escrito que "nace como consecuencia directa de los ataques sufridos por los conversos y principalmente por los sufridos en la ciudad de Toledo durante el 1449"54. En esta obra el obispo de Burgos, sin renunciar a seguir presentando algunas consecuencias políticas de la metáfora organicista, se va a introducir en sus derivaciones sociales y, sobre todo, religiosas, aquéllas a las que más sensibles se mostraban los conversos como él. Para ello recurrirá, como era frecuente entre quienes se identificaban con el hombre nuevo de la teología paulina, a las enseñanzas del "Apóstol”.

\footnotetext{
${ }^{53}$ Qüestión, 357.

${ }^{54}$ G. VERDÍN-DÍAZ, Introducción a Alonso de Cartagena y el Defensorium Unitatis Christianae (Introducción bistórica, traducción y notas), o. cit., 15.
} 
El origen y desarrollo histórico de los ataques a los conversos que provocan la escritura del Defensorium han sido objeto de repetidos análisis ${ }^{55}$. Los acontecimientos se inician cuando el condestable Álvaro de Luna, favorito del rey Juan II, exige a los toledanos un millón de maravedíes para sufragar la guerra contra los moros, la rebelión de algunos nobles (en parte excitados contra lo que consideraban un excesivo poder del Condestable) y los ataques del Reino de Aragón, que unos días antes había invadido las regiones de Requena y Utiel ${ }^{56}$. Los habitantes de Toledo se resistieron al préstamo alegando antiguos privilegios, los mismos que fueron desechados por el ministro real ante la necesidad urgente que reclamaba la situación. A su vez, la indignación del pueblo creció al ver en la empresa la intervención interesada de los conversos toledanos, especialmente la del rico mercader Alonso Cota, recaudador de los tributos. Cuando ocho días después de la solicitud del préstamo, el 27 de enero de 1449, el pueblo se reúne en ausencia de don Álvaro, es encendido por una serie de caudillos que provocan su ataque: primero la casa y los bienes de Alonso Cota y, después, el barrio de la Magdalena, donde vivían los conversos más ricos de Toledo, son saqueados. Lo paradójico es que el levantamiento se convierte en abierta rebelión al ponerse al frente de la muchedumbre quien estaba encargado de mantener el orden ciudadano: el alcalde mayor Pero Sarmiento. Éste y su ayudante, el bachiller Marcos García de Mora, dirigen a los rebeldes, toman los puntos estratégicos de la ciudad y se disponen a resistir la autoridad real hasta que sea cesado el condestable Álvaro de Luna. Sin pérdida de tiempo, el alcalde comienza a apoderarse de los bienes de los negociantes conversos en nombre del rey.

Poco tiempo después de estos hechos, van a empezar a aparecer una serie de documentos: la Sentencia-Estatuto (5.VI.1449) de Pero Sarmiento que privaba a los cristianos nuevos de ocupar cargos en la ciudad de Toledo, dos bulas de excomunión de los rebel-

\footnotetext{
${ }^{55}$ E. BENITO RUANO, Toledo en el siglo XV. Madrid. CSIC, 1961; N. ROUND, "La rebelión toledana de 1449”, Archivum (Oviedo), XVI, 1966, 385-446, y J. LAWRANCE, "Alfonso de Cartagena y los conversos", en A. DEYERMOND y R. PENNY, eds., Actas del primer Congreso Anglo-Hispano. Tomo II. Literatura. Madrid. Castalia, 1993, 103-20.

56 Defensorium, Tercera parte, capítulo tercero, 355: "estas cosas coincidieron con las incursiones hostiles de algunos de nuestros vecinos del reino colindante y con los ataques de los mercenarios que dentro de nuestro propio reino nos perturbaban la paz. En esta afluencia de desgracias estos sediciosos agitadores de la plebe se encargaron de alterar el sosiego de la paz que florecía en el centro del reino para que los problemas nos quebrantasen por todas partes. Y para colmo escogieron para llevar a cabo estas revueltas precisamente el momento en que nuestros viejos enemigos mahometanos arrasaban toda la Vandalia destruyendo fortalezas y pueblos, apoderándose de numerosa muchedumbre de hombres y mujeres cristianos, así como de inocente niños, y convirtiéndolos en miserables esclavos".
} 
des (24.IX.1449) del Papa Nicolás V (una por delito de lesa majestad, por rebelión contra Juan II, y otra por intentar romper la unidad cristiana y promover un cisma religioso), así como el Memorial contra los conversos del bachiller Marcos García (de octubre o noviembre de 1449, puesto que en él protesta contra las bulas de excomunión). Los escritos de los rebeldes serían respondidos desde un punto de vista jurídico por el doctor Alonso Díaz de Montalvo, siguiendo el encargo de Juan II, y por Fernán Díaz de Toledo (Instrucción del Relator), comisionado a su vez por Lope de Barrientos, obispo de Cuenca. En la línea de estas dos últimas, la respuesta más completa y profunda y la que adquiere categoría filosófica y teológica, digna de quien era un persuasivo argumentador y un experto letrado, es la que proporciona el obispo de Burgos a finales de 1449 o inicios de 1450 con su Defensorium $^{57}$. Desde el inicio de esta obra dirigida al rey Juan II, se subraya la unidad de la Iglesia, que las pasiones de "algunos" han venido a poner en riesgo ${ }^{58}$, y para demostrarlo, su primera parte se sumerge en una lectura del Antiguo Testamento que pretende mostrar no sólo la unidad e igualdad ante Dios del género humano hasta Babel, sino su reinstauración tras la venida del Hijo ${ }^{59}$.

El interés del obispo Cartagena por afirmar esa unidad e igualdad de todos los creyentes aleja el Defensorium de la visión judía del pueblo escogido, y le permite interpretar la Biblia desde la perspectiva de un converso cuya mayor aspiración es dejar sentado que

57 A. A. SICROFF, Los estatutos de limpieza de sangre. Controversias entre los siglos XV y XVII. Madrid. Taurus, 1985 (1958), 61-2: "El acta de acusación de la Sentencia-Estatuto por Alonso Díaz de Montalvo es al Defensorium de don Alonso de Cartagena lo que un prefacio a un análisis profundo. El jurista planteó una cuestión fundamental, la de la unidad de la Iglesia cristiana, y Alonso de Cartagena empleó toda su erudición de teólogo y toda su elocuencia para explorar los diversos aspectos del problema. Hizo un estudio tan profundo que durante dos siglos los abogados de los cristianos nuevos no encontraron nada que añadir a las consideraciones teóricas expuestas en el Defensorium. En efecto, este último fue utilizado como manual del que los conversos sacaban la mayoría de sus argumentos".

58 Defensorium, Primera parte, Prólogo, 101: “A Vuestra Regia Majestad, poderosísimo Señor, no hace mucho yo le había escrito algunas cosas que se me iban viniendo al pensamiento para exhortar y reducir a aquellos, porque algunos hay, a quienes la inadvertencia, la ignorancia, la envidia u otra pasión del alma de esas que, oh, dolor, muchas veces siente el espíritu humano- les hizo precipitarse en una duda, vacilación, pensamiento, creencia o afirmación que de alguna manera podría dañar la unidad de la iglesia católica, que es la sola, la única y muy querida Paloma [Cantar de los Cantares 6, 9] purísima, sin mancha o arruga [Efesios 5, 27], o que podría dañar la unidad del pueblo cristiano que vive fielmente bajo ella como bajo piadosísima madre de todos los fieles, y desgarrar la inconsútil túnica [Juan 19,23] de Cristo con algún rasguño".

59 Ibídem, Primera parte, capítulo décimo, 135: "En Cristo, pues, esplendor eterno y segundo Adán sin mancha, se disipó toda la ceguera de los ojos del corazón de una y otro gente, y cesó toda diferencia de pueblos y de linaje, porque todos volvieron en este segundo Adán puro a la unidísima unidad. Porque así como del primer Adán, por la propagación de la carne, todos los hombres participantes de la naturaleza humana se pusieron en marcha hacia la muerte, así por Cristo, que es el verdadero, nuevo e inocente Adán, todos los hombres, hechos partícipes de la divina gracia por regeneración espiritual, pasarían a la vida sin preferencia de linaje alguno". 
deben existir las mismas exigencias y posibilidades para los de su origen que para los cristianos viejos. Pero, por si hubiera alguna resistencia, siempre cabe recordar que los que eran totalmente desconocedores del Antiguo Testamento y, por tanto, tenían más dificultades para comprender el mensaje del Nuevo eran los gentiles, mientras "que los descendientes del pueblo israelita no llegan a la ley como si nunca la hubieran oído y como a algo nuevo que se les ha ofrecido recientemente, sino que llegan a la ley como a complemento de la ley escrita y de su plenísima perfección"00. Con esta visión, la Iglesia aparece como el verdadero Israel, donde los judíos pueden encontrar su auténtica identidad y destino ${ }^{61}$.

Para afianzar la idea de unidad de los fieles de cualquier procedencia nada mejor que apelar a la imagen del corpus mysticum, donde los convertidos se integran por el bautismo, beneficiándose inmediatamente del favor divino: "El bautismo incorpora a los bautizados a Cristo como miembros y de él, como cabeza, discurre por los miembros la plenitud de su gracia y de su virtud" 62 . Esta gracia afecta al individuo en tanto que tal, por encima de su pertenencia de origen a uno u otro grupo. Cartagena logra así conciliar la hermandad entre los hombres con la consideración individual de los méritos de cada cual; una situación que localiza al principio de la historia humana, tras la muerte de Abel y el nacimiento de las religiones paganas, y en la que el Defensorium no dejará de insistir ${ }^{63}$.

El valor de la persona, que es la que se inserta en el cuerpo de Cristo y se constituye como uno de sus miembros, y no, por tanto, el dato de su procedencia, convierten a cada cual en responsable de sus propios méritos, lo que anula cualquier pretensión de privilegio o perjuicio por pertenecer a cualquier pueblo o grupo de parentesco ${ }^{64}$. La metáfora organicista desempeña así una triple función: igualadora, unificadora y gratificadora. En virtud de la primera, se reconoce exclusivamente a los individuos, que se integran todos ellos

${ }^{60}$ Ibídem, Primera parte, capítulo sexto, 122; véase Segunda parte, Teorema cuarto, capítulo vigésimo octavo, 316.

${ }^{61}$ N. G. ROUND, "Politics, style and group attitudes in the Instrucción del relator", Bulletin of Hispanic Studies, 46: 4 (1969, Oct.), 289-319 (303).

${ }^{62}$ Defensorium, Segunda parte, Teorema primero, capítulo octavo, 171.

${ }^{63}$ Ibídem, Primera parte, capítulo primero, 108: "el género humano se dispersó en diferentes y contrarios modos de vivir: algunos realmente sirviéndose de la luz de la razón natural siguieron una vida honesta que va pareja con cierto conocimiento de Dios; otros, en cambio, engreídos al ignorar al Dios verdadero, procedieron a crearse dioses falsos. De aquí arrancó el yerro de los muchos dioses y de otras varias supersticiones. Sin embargo, la gente de todo el universo era igual y, ante Dios, en cuanto a origen, ninguna precedía a la otra a favor alguno, sino que cada uno de los hombres, con la colaboración de la divina gracia, conseguía aquel favor que nacía de los méritos propios".

${ }^{64}$ Ibídem, Primera parte, capítulo primero, 109: "Se daba, pues, importancia a las obras de cada uno, no a la descendencia de una determinada familia o linaje". 
en igualdad de condiciones como miembros del corpus mysticum; por la segunda, los distintos miembros llamados a engrosar la grey cristiana, sea cual sea su origen, se unen en un solo cuerpo, el de Cristo, que es la Iglesia; pero, a la vez y en tercer lugar, ese cuerpo ejerce una función santificadora: al unirse al cuerpo de Cristo todos los fieles reciben su gracia, lo que los libera del pecado. Esa nueva situación los equipara bajo la cabeza de Cristo, de manera que no sólo pierde su razón de ser cualquier referencia a la procedencia, olvidada al adquirir individualmente los fieles por el bautismo su nueva condición, sino que incluso diluye cualquier nueva distinción religiosa que se intente establecer pues, en tanto que miembros de un mismo cuerpo, todos afirman su utilidad y todos quedan englobados dentro del mismo. Una conclusión que resultaba especialmente valiosa para los conversos frente a la preferencia por el linaje que pretendían hacer valer los cristianos viejos. De hecho, Cartagena no deja de recordar que la existencia de antecedentes gentiles, aunque en menor medida que israelitas, en la propia genealogía de Cristo, era un síntoma evidente de la superación de las diferencias que pudieran existir antes de que se extendiera su mensaje ${ }^{65}$.

La metáfora del corpus mysticum viene a dar expresión al mensaje universalista cristiano que equipara a todos los creyentes, conversos o cristianos viejos, en la Iglesia. Pero la preferencia de Alonso de Cartagena por la interpretación horizontal de la metáfora, la que recalca la unidad de los miembros del cuerpo, no le impide exprimirla en busca de otras consecuencias; en concreto, aquellas que guardan relación con las diferencias sociales. Por eso, la segunda parte del Defensorium, se embarca en la defensa de los privilegios de los convertidos ("la calidad de las personas y otras excelencias y cualidades singulares"), lo que para un integrante de la elite social castellana, como era su autor, no podía ser una tarea a descuidar. Lo que quiere dejar sentado Cartagena es que la nobleza de los judíos no se pierde con la conversión ${ }^{66} \mathrm{o}$, lo que es lo mismo, que si el bautismo anula el pecado,

\footnotetext{
${ }^{65}$ Ibídem, Segunda parte, Teorema tercero, capítulo primero, 189: "De estos dos grupos que mencionamos [israelitas y gentiles] es bien sabido que cuando acceden a la fe católica se forma una sola Iglesia, un solo pueblo, un solo cuerpo, cuya cabeza es Cristo. Toquemos ligeramente este punto de la manera sumaria que nos fuere posible. Lo que sea primero en dignidad, aunque intermedio en el tiempo, no debe por esta razón preceder al resto de los testimonios porque el mismo Jesucristo que es la verdadera y suprema cabeza nuestra y cuyo único cuerpo es toda la Iglesia y el pueblo católico de cualquier parte que procediere, aunque de una manera más fundamental proceda de uno, sin embargo, según la carne nació de uno y otro de tal modo que nos haría a todos uno en su oculta divinidad".

${ }^{66}$ Ibídem, Segunda parte, Prólogo, 142: "Que tanto entonces como ahora los que arriban a la fe católica recuperan de nuevo la aptitud para obtener cualquier excelencia, nobleza, u otra dote cualquiera que en principio tenían, siempre que para recuperarlas no se opongan a los principios de la autoridad de la Iglesia".
} 
anula también los impedimentos que pudiera haber en la sociedad civil como consecuencia del mismo. Quien es recibido como nuevo miembro del cuerpo de Cristo, ve abiertas las puertas a ese cuerpo místico que también es el corpus morale et politicum en el sentido aristotélico y, convertido en uno más de sus integrantes, siente derribarse cualquier obstáculo que pudiera impedir el reconocimiento de sus "honores de esta vida" ${ }^{67}$. Para el obispo de Burgos negar esto viene a ser lo mismo que caer en la herejía, pues supone tanto como rechazar la validez del bautismo, que es un sacramento que infunde a quien lo recibe gracia y virtudes ${ }^{68}$.

Sin embargo, a nadie escapa que el honor se reparte de forma desigual en todas las sociedades, sean de judíos, de gentiles o de fieles. Por tanto, la restauración del honor de los judíos convertidos no puede darse por igual, sino que tendrá que asentarse sobre las diferencias existentes. Al fin y al cabo, la gracia equipara en lo religioso, pero deja intactas las diferencias civiles de origen, lo que significa que a cada nuevo miembro le debe corresponder el mismo oficio o condición que poseía cuando no era parte del corpus mysticum:

"No se puede, por tanto, dudar que cualquier israelita, al igual que cualquier otro, una vez limpio del pecado de infidelidad por el agua del bautismo, en la medida que le corresponda será partícipe del honor tanto eclesiástico como civil, de modo que el rústico se sienta igual entre los rústicos, el plebeyo entre los plebeyos, el de pueblo entre los de pueblo, el mercader entre los mercaderes, el soldado entre los soldados, el noble entre los nobles, el sacerdote entre los sacerdotes, y así sin interrupción hasta recorrer todas las escalas del gobierno eclesiástico o político, respetando siempre la preeminencia y honor de los más nobles y de las familias sobresalientes, ya que la nobleza no es exactamente la misma en todos los nobles, porque algunos nobles son más nobles que otros" 69

\footnotetext{
${ }^{67}$ Ibídem, Segunda parte, Teorema cuarto, capítulo duodécimo, 256: “¿Qué mayor alejamiento de la vida pasada o qué mayor renovación puede darse, una vez rechazada la infidelidad, que aquella que por medio de la recepción de la fe se produce con la purificación sacramental por la cual surge el hombre nuevo al despojarse completamente del hombre viejo? Del hombre viejo, por consiguiente, no queda impedimento, o mancha, de tal manera que puede alcanzar tanto la salvación del alma como los honores de esta vida, si no hay cosa alguna especial en contra de su persona”.

${ }^{68}$ Ibídem, Segunda parte, Teorema cuarto, capítulo decimosexto, 269: “en el bautismo se infunden gracia y virtudes, es lógico que el que sostiene que al bautizado, sin culpa propia, se le ha de negar el honor debido, ya en la muestra de respeto que pertenece a la forma general, ya en la exaltación de la persona virtuosa que pertenece a la forma especial de honor adecuado a la cualidad de la persona y de las cosas, necesariamente afirma una de las dos cosas: o que en el bautismo no se infunden virtudes, lo que va contra la fe católica, o que a la virtud no se le debe honor, lo que va completamente en contra de la doctrina filosófica y de toda política de gobierno. Si obstinadamente se afirma lo primero es herético, si lo segundo, es insensato y de una extremada locura".

${ }^{69}$ Ibídem, Segunda parte, Teorema cuarto, capítulo decimosexto, 269.
} 
Así pues, Alonso de Cartagena, en un giro que resalta más cuando se observa sobre el fondo de la equiparación religiosa anteriormente establecida, reconoce que ésta no anula el distinto mérito social que poseen los integrantes de la sociedad, de manera que se hace necesario admitir la nobleza y el honor que en la vida social algunos poseen en mayor medida que otros. Lo conversos no son, a este respecto, distintos de los cristianos y su nobleza como judíos se traslada a su nueva situación. La armonía entre quienes comparten una misma fe no elimina los contrastes entre quienes poseen distinto estado y profesión; tras la conversión no importa la raza, pero es ineludible el mantenimiento de la diferencia social. Desde este supuesto, se añade ahora al uso horizontal de la metáfora en lo que afectaba a la consideración religiosa de los individuos, el reconocimiento de las jerarquías sociales, por cuanto se admiten los méritos distintos que algunos atesoran por su oficio o -aquí sí- linaje:

"Por consiguiente, por la unidad del nuevo cuerpo podremos apreciar cuán grande es la unidad de los fieles entre sí. Porque aunque tengamos muchos miembros, y el uno sea más noble que el otro por la diferencia de funciones que les corresponden para atender con solicitud al todo, sin embargo, cualquier daño que se le haga a uno de los miembros afecta a los otros, ya que en su debida proporción se ayudan mutuamente. Así pues, bajo la unidad del cuerpo de la Iglesia, aunque un individuo sea más digno de honor que otro por diversas excelencias que quizás concurran en él, sin embargo, en lo que se refiere a la universalidad de integrar el cuerpo como un todo y de ser llamado miembro como otro cualquiera, no hay ninguno despreciable, sino que todos son iguales. Y así como el ojo no puede decir al pie que no es un miembro, aunque él por su oficio visual sea más sobresaliente, delicado y honroso, de la misma manera en el cuerpo de la Iglesia, en que los miembros fieles tienen diferentes oficios y unos son, en cierto modo, semejantes al ojo, otros a la lengua, otros a los brazos, otros a los pies, y a alguno a causa de un oficio superior o de una ilustre nobleza o de cualquier otra particular excelencia haya que honrarlo más que a otro, sin embargo, todo fiel, de cualquier origen que sea, es un miembro íntegro y apto, de manera que bajo la imagen de miembro conveniente sea colocado por la providencia de la Iglesia en el lugar adecuado"70

Es evidente que el Defensorium presenta en ocasiones un carácter polémico que pretende dar cuenta de los ataques que aspiraban a convertir a los conversos en cristianos y ciudadanos de segunda clase; en este sentido hay que interpretar las referencias al bachiller Marcos. Sin embargo, más allá de las circunstancias concretas que motivaron su escritura,

\footnotetext{
${ }^{70}$ Ibídem, Segunda parte, Teorema tercero, capítulo sexto, 210.
} 
lo que compartiría con el resto de las obras de don Alonso $^{71}$, su objetivo es mucho más ambicioso: quiere resolver cualquier problema que pueda ensombrecer la integración de los conversos en la Iglesia. Por eso, en la tercera parte del Defensorium, su autor no duda en convertir los obstáculos a esa integración en un crimen que debe ser castigado por el propio monarca:

"Todo lo anterior lo intercalé con la intención de denunciar con qué sumo cuidado los muy poderosos príncipes deben estar atentos a arrancar de raíz, por mínimo que parezca, cualquier error que intente brotar, nacer o levantarse, directa o indirectamente, pública u ocultamente, contra la fe católica o contra las cosas tocantes a ella. Fácilmente pueden darse cuenta que de la misma insensibilidad del crimen se puede pasar por proximidad y peligro de contagio a otros pecados enormes, pues no hay que considerar mínimo nada que vaya contra la fe. Por muy de poca importancia que parezca hay que ponerle remedio sin dilación, como a un incendio cualquiera" 72

La defensa espiritual y social de los conversos que Cartagena mantiene no está, sin embargo, libre de costes. Las críticas hacia los que se convertían pero mantenían un vínculo con sus viejas creencias y a los judíos que permanecían fieles a su fe no dejaban de perjudicar a los conversos sinceros. Los ataques a los conversos toledanos demostraban el fácil deslizamiento de la opinión antijudía a la de los cristianos nuevos. Por eso el Defensorium se esfuerza por establecer distancias entre unos y otros. Para los conversos recientes, Cartagena apela a la comunidad de los hombres que ya daba por supuesta en sus tempranas traducciones de Cicerón y que reiteró en buena parte de sus obras: mantiene no sólo la igualdad y hermandad de los creyentes por encima de su origen, sino también la necesidad de ser comprensivo con aquéllos que, recién incorporados, pueden experimentar en su carne la tentación de dar marcha atrás en su nueva fe. Lejos de aceptar la llamada a su exclusión, para éstos también es válido el mensaje uniformador de la metáfora organicista

\footnotetext{
${ }^{71}$ J. LAWRANCE, "Alfonso de Cartagena y los conversos", 110: "todas las obras de Cartagena son circunstanciales, frutos de una consulta previa. No escribía por cuenta propia, sino que ponía su elocuencia al servicio de sus señores, que tantas dignidades habían conferido en él”; L. FERNÁNDEZ GALLARDO, "Las ideas políticas de Alonso de Cartagena", Res Publica. Revista de filosofía politica, 18 (2007), 413-26 (414): "Sus obras son en buena medida obras de circunstancias, compuestas a partir de la petición del rey o de un magnate con un cometido muy específico que condiciona considerablemente las estrategias argumentativas propias de cada texto".

${ }^{72}$ Defensorium, Tercera parte, capítulo sexto, 367.
} 
pues, como miembros del mismo cuerpo, la caridad cristiana debe verse aplicada sobre ellos con más cuidado y delicadeza que sobre los miembros firmes ${ }^{73}$.

Con quien no cabe contemporizar es con los herejes y los propios judíos. De estos últimos, que se resisten a integrarse en el corpus mysticum, Cartagena tiene necesidad de distanciarse, y su mensaje no deja lugar a dudas:

"No pueden, pues, ser llamados inteligentes cuando no encaminan sus acciones a un buen término, aunque algunas veces en las cosas pequeñas parezcan ingeniosos, porque la agudeza que tiende hacia un mal fin, como dice Aristóteles, no es sabiduría, sino astucia. Por lo tanto al no usar enteramente de la inteligencia como conviene, parecen esforzarse en la servidumbre natural. Tienen necesidad, pues, de un guía que les dirija por el camino de la salvación eterna. Por este motivo es muy conveniente que, como carentes de entendimiento, escuchen, quieran o no, a los predicadores católicos para que éstos, como tutores de menores o como cuidadores de necios, los aconsejen y los exhorten a recibir la fe. Y aunque en un principio el oír estar cosas les resulte desagradable, poco a poco, sin embargo, al ir abriéndoseles los ojos del alma se darán cuenta de que es algo muy dulce y muy grato" 74

La tutela de los predicadores cristianos sobre los que con su comportamiento no demuestran sino su corto entendimiento de la verdad, es la receta del obispo Cartagena para los judíos pertinaces. Para aquellos otros que, tras la conversión, se deslizan a la herejía y se niegan a corregirse, la solución es mucho más tajante: el mismo castigo del poder secular que se solicita para los rebeldes toledanos ${ }^{75}$.

\footnotetext{
${ }^{73}$ Ibídem, Segunda parte, Teorema cuarto, capítulo decimocuarto, 262: “¿Quién, por consiguiente, honesto e inteligente, podrá dudar que a los hombres de esta clase como a los otros que viven en la fe católica hay que tratarlos con el debido honor de acuerdo con la categoría de sus personas, eliminando toda diferencia de primitivo origen, y que deben ser tratados tanto más delicada cuanto más recientemente hayan llegado a la fe, a la manera del apóstol que a los neófitos en la fe como a niños recién nacidos les daba leche, no comida sólida? Con lo que no quiero decir que éstos han de ser tratados de diferente manera que los demás, sino que bajo la unidad de un mismo cuerpo si advertimos que algunos son débiles, que los aliviemos con la leche de la caridad y con los pechos de la generosidad, como en un mismo jardín a las plantas más tiernas se las riega más a menudo con abundancia de buena agua".

${ }^{74}$ Ibídem, Segunda parte, Teorema cuarto, capítulo séptimo, 238.

${ }^{75}$ Ibídem, Tercera parte, capítulo noveno, 375: "En consecuencia no solo creo que hay que eliminar de los términos cristianos el error de los que quieren introducir las diferencias de origen carnal, sino que también hay que purificar y arrojar muy lejos toda suciedad e inmundicia de los que vuelven a caer en la ceguera del judaísmo o de cualquier paganismo o sórdida secta. ¿Quién lo duda? Y donde quiera que con indicios de certeza haya sospecha de algún error, aquél a quien le compita por obligación debe hacer uso de habilísima escrupulosidad para sacarlo a la luz, y los que fueren encontrados culpables vuelvan al buen camino de acuerdo con las disposiciones canónicas, si renuncian a la herejía; en cambio, los obstinados o los declarados por la autoridad eclesiástica como reincidentes en herejía, negada con falso juramento, sean castigados por el poder secular con muy justa severidad".
} 


\section{La metáfora organicista y la rebelión toledana.}

Los profundos argumentos de Cartagena no dejan de lado la situación de la ciudad de Toledo. También aquí, su doctrina organicista vinculada a la monarquía se ofrece como una alternativa a lo que percibe como un ataque popular, esto es, democrático: una ciudad es un corpus mysticum compuesto de materia (la plebe) y forma (la nobleza). Si el gobierno de la ciudad no cambia o lo hace en escasa medida, ese corpus se mantiene. Pero si los cambios se producen hasta alcanzar a introducir un régimen de gobierno diferente, la ciudad deja de ser lo que fue y se convierte en un cuerpo diferente; también si se pierde la forma, la ciudad deja de ser un todo orgánico, y los individuos que la constituyen, aunque sigan allí, no son sino una muchedumbre ${ }^{76}$. Una situación de este tipo es la que se ha dado en Toledo, una ciudad de régimen aristocrático en la que el rey nombra a las autoridades; cuando, como ha ocurrido, éstas son rechazadas por la plebe, hacen que la ciudad pierda su forma, quedando convertida su materia en una masa inorgánica:

“en aquellas ciudades que tienen en el príncipe al rey supremo no se puede establecer un gobierno legítimo sin su expreso reconocimiento, o sin una larga tradición que lo reconozca, sobre todo, porque real y verdaderamente, no puede existir gobierno, si no existe potestad de mandar, y de administrar justicia, y de gobernar la república de aquella ciudad. Y esta potestad procede del mismo rey; el pueblo no puede otorgar autoridad contra la tradición, ni contra la voluntad del rey. Y como esta voluntad, expresa o tácita, de Vuestra Majestad no se da, la plebe, en definitiva, aunque permanezca en la misma urbe, según el derecho no alcanza el nombre de ciudad y se queda bajo el nombre de (la) turba o plebe o muchedumbre de gentes" 77

Lo que procede, por tanto, es la restauración de la auténtica forma de la ciudad y el castigo de los responsables de su pérdida temporal. Aunque todos los que se han levanta-

\footnotetext{
${ }^{76}$ Ibídem, Tercera parte, capítulo decimotercero, 392: "Esta, pues, manera de gobernar da configuración a las ciudades de modo que en ellas el senado y el orden de decuriones y todos aquellos que tienen el cuidado de la república por la fuerza de la autoridad establecida, representa la forma; la plebe, que está bajo estas, representa la materia. Y así resulta que el cuerpo místico compuesto de esta forma y materia se llama ciudad. Mientras se mantenga firme esta composición, aunque bajo la misma particular especie se cambie algo, la ciudad es categóricamente la misma, pero si la forma desaparece y subrepticiamente penetra otra, la que existía se destruye y nace otra ciudad nueva. Y si por casualidad, eliminada la forma, no le sigue ninguna otra forma de ciudad, aunque la gente permanezca la misma, al no estar ligada políticamente por nada legítimo, la primera ciudad deja de ser y no se forma una nueva. La gente que permanece en ella puede recibir el nombre de tropel de gentes, $u$ otro que signifique aglomeración de hombres, pero no puede de ninguna manera recibir el nombre de ciudad, exactamente igual que el cadáver de un hombre indica que ha existido un hombre, pero que el hombre ya no existe".

77 Ibídem, Tercera parte, capítulo decimocuarto, 395. S. GARCÍA-JALÓN, "La noción de «cuerpo místico» en Alonso de Cartagena”, Helmantica, 43, 132, 1992, 409-14, reduce su análisis sólo a esta aplicación.
} 
do contra el gobierno legítimo son culpables, hay que castigar con especial severidad a los demagogos, como el bachiller Marquillos, que han llevado al levantamiento del pueblo contra el rey ${ }^{78}$. Sólo a éste corresponde poner en orden el organismo ciudadano:

"Porque así como el individuo humano, anulado por la ausencia del alma, algunas veces uniéndolo milagrosamente el Dios omnipotente lo hace vivir, así Vuestra Alteza Real, que ocupa el lugar de Dios en la tierra, al individuo místico de esta ciudad, disuelto por la violencia de la democracia que trata de penetrar, restitúyalo vivo a su primitiva naturaleza de vida, devolviéndolo a su orden aristocrático, para que como el mismo Job, el orden mismo de la ciudad, y no otro, sea restablecido, para que la ciudad, como otro Lázaro, levantándose del sepulcro después de cuatro días, libre de toda atadura, se pliegue a la voluntad de Vuestra Majestad" 79

La metáfora organicista viene a cumplir así su último designio: en virtud de sus orígenes paulinos se erige en avalista de la igualdad religiosa de todos los fieles, mientras que su aplicación civil, en la que se encuentra más que presente la influencia aristotélica, se convierte en instrumento de cohesión social. En uno y otro caso se reconoce el papel dirigente del monarca. Que todo ello esté presente en las obras de Alonso de Cartagena varias décadas antes de que comenzase en España la influencia de Erasmo, invita a poner entre interrogaciones el dicho de Bataillon, según el cual "la imagen paulina del cuerpo, cuyos miembros son los cristianos y cuya cabeza es Cristo, [es una] imagen cuya popularidad en España parece poder atribuirse al Enchiridion"80.

\footnotetext{
* Este artículo se ha realizado en el marco del Proyecto de Investigación del MICINN FFI2010-15582 "Legitimación del poder político en el pensamiento medieval".
}

\footnotetext{
${ }^{78}$ Ibídem, Tercera parte, capítulo decimocuarto, 396: “A estos, pues, es a quienes hay que aplicar una disciplina más rigurosa cuando la plebe comete un error. Porque aunque todos los partícipes de un delito son culpables, sin embargo, hay que considerar como más gravemente culpables a los agitadores que, bajo apariencia de conseguir liberación de impuestos o de expulsar a los que tienen autoridad, provocan revueltas de esta índole para que la plebe, haciéndose fuerte, se apropie del poder o de la libertad ilícita. Estos, pues, con razón son dignos de castigo, porque con la astucia de la persuasión embaucan al pueblo ingenuo".

${ }^{79}$ Ibídem, Ultílogo, 399.

${ }^{80}$ M. BATAILLON, Erasmo y España. Estudios sobre la historia espiritual del siglo XVI, 541.
} 